\title{
Storage substances in the androgametogenesis and mature pollen grain of Ilex paraguariensisSt. Hil. (Aquifoliaceae) ${ }^{1}$
}

\author{
RINALDO PIRES DOS SANTOS ${ }^{2}$ and JORGE ERNESTO DE ARAUJO MARIATH ${ }^{2,3}$
}

(recebido em 12/03/98; aceito em 16/11/98)

\begin{abstract}
Storage substances in the androgametogenesis and mature pollen grain of Ilex paraguariensis St. Hil. (Aquifoliaceae)). Storage substances such as starch grains, proteins and lipids were studied during the male gametogenesis and in the mature pollen grain of Ilex paraguariensis St. Hil. (Aquifoliaceae). There are two cycles of amylogenesis and amylolyse. The first cycle lasts until the vacuolated stage when the starch is hydrolyzed and amorphous proteins are stored inside the single vacuole. The next cycle begins after mitosis with the formation of the vegetative and generative cells. At this point, the young vegetative cell stores many starch grains that are bigger than in the first cycle. During the maturation of the male gametophyte, the starch is hydrolyzed and it is absent in the mature pollen grain. Small lipid droplets surround the young generative cell after the mitosis of the androspore and are dispersed in the vegetative cytoplasm during its maturity. The relationship between the pollen storage substances and the ontogeny of the layers in the sporoderm, formation of the generative cell, and the male germ unit were discussed.
\end{abstract}

RESUMO - (Substâncias de reserva na androgametogênese e grão de pólen maduro de Ilex paraguariensis St. Hil. (Aquifoliaceae)). A presença de substâncias de reserva na forma de grãos de amido, proteínas e lipídios foi analisada durante a gametogênese masculina em Ilex paraguariensis St.Hil. (Aquifoliaceae). Foram encontrados dois ciclos de amilogênese e amilólise. O primeiro estende-se até a fase de andrósporo vacuolado, quando todo o amido presente é hidrolizado e proteínas, na forma amorfa, são estocadas no interior do único vacúolo do andrósporo. O segundo ciclo inicia a partir da formação das células generativa e vegetativa, sendo que esta última estoca grande quantidade de grãos de amido, maiores que os do primeiro ciclo. Todo o amido é hidrolizado durante a maturação do andrófito e a formação da unidade reprodutiva masculina. Gotas lipídicas circundam a célula generativa durante seu englobamento e estão dispersas no citoplasma vegetativo no andrófito maduro. A síntese e degradação de substâncias de reserva podem estar relacionadas com a formação dos estratos da esporoderme e ontogenia do andrófito binucleado.

Key words - Storage substances, starch, pollen ontogeny, Aquifoliaceae

\section{Introduction}

The male gametophytical generation of the Angiosperms, the androphyte (also known as "pollen grain"), undergoes a series of morphological and physiological changes until reaching maturity and being able of generate the pollen tube, the cellular medium of sperm conduction. Structurally and functionally, the pollen grain is a fascinating organism, because of its nature of independent haploid plant, which is extremely reduced and in the maturity shows two or three cells enveloped by a resistant wall, the sporoderm. Among the changes that occur in the pollen grains during their ontogeny, the storage of substances, until the maturity or fully degraded, was described in many species of Angiosperms (Baker

1. From the M. Sc. work of R.P. dos Santos, CNPq, Universidade Federal do Rio Grande do Sul.

2. Laboratório de Anatomia Vegetal, Departamento de Botânica, Universidade Federal do Rio Grande do Sul, Av. Paulo Gama 40, Prédio 12106, 90046-900 Porto Alegre, RS, Brazil. E-mail: mariath@botanica.ufrgs.br

3. $\mathrm{CNPq}$ researcher.
\& Baker 1979). Starch grains and P-particles are the most frequently found polysaccharides during the pollen ontogeny. Starch is an insoluble polysaccharide stored in plastids (amyloplastids). When present in pollen grains it derives from the polymerization of sugars during the photosynthetic activity of sporophyte, which reaches the growing spores through direct contact with the tapetum (plasmodial type) or the locular fluid (secretor type). The P-particles are spherical vesicles with a large content of polysaccharides that lose their membranes during the pollen tube growth (Heslop-Harrison 1979). Lipids are encountered like droplets in the cytoplasm and the proteins are stored in vacuoles or vesicles of the endoplasmic reticulum.

The mature pollen grains of Ilex paraguariensis (the maté) do not have starch in the vegetative cell. However, starch grains and proteins are present in large amounts in the gametogenesis (R.P. dos Santos, unpublished data). In this paper we presented the changes occurred in the storage substances such as starch, proteins and lipids during the male gametophyte formation and their possible physiological and ecological significance. 


\section{Material and methods}

Inflorescences of staminate plants of Ilex paraguariensis St. Hil. (Aquifoliaceae) were collected at Fundação Zoobotânica do Estado do Rio Grande do Sul (FZB), in Porto Alegre, RS. The samples ranged from flower buds in different stages of development to flowers in anthesis. The proof material is stored in the Herbarium of the Department of Botany (ICN) of the Universidade Federal do Rio Grande do Sul, under number ICN 96709. The floral development was accompanied in 10 floral buds, from $1 \mathrm{~mm}$ of diameter through anthesis, with periodic diameter measures.

The material collected was divided and classified according to anther dimensions related to the pollen development stage. The floral buds were measured, drawn and dissected in a Wild stereomicroscope, model M7A, with a drawing device. Before complete removal of the anthers in each bud, one of them was removed, squashed between slide and cover glass and previously inspected without staining under bright field microscopy to determine the contents of the androsporangia. Finally, the other ones were measured and processed for light and electron microscopy. Light microscopy - The anthers were fixed in a solution of glutaraldehyde $2 \%$ in phosphate buffer $0.1 \mathrm{M} \mathrm{pH} 6.8$ (Gabriel 1982) at $4^{\circ} \mathrm{C}$ for two hours. After fixation the material was washed in the same buffer, dehydrated in alcoholic series and embedded in hydroxyethylmetacrylate-based plastic resin. The semithin sections were cut in a Leitz microtome, model 1400 , using a profile $\mathrm{D}$ knife and a thickness of 1 to $2 \mu \mathrm{m}$. The sections were floated in water at room temperature then distended and mounted on histological slides on a warmed plate at $60^{\circ} \mathrm{C}$.

The combination of PAS with toluidine blue $0.05 \%$ in benzoate buffer $\mathrm{pH} 4.4$ (O’Brien \& McCully 1981) for staining was used to locate total polysaccharides. Coomassie blue $0.1 \%$ (Southworth 1973) was used for the identification of proteins. Black and white photomicrographs were made in a Leitz bright field microscope, model Dialux $20 \mathrm{~EB}$, using green filter VG9, for PAS reactions and rotorange 42 filter, for Coomassie blue stain.

Electron microscopy - The anthers were fixed and washed as described above. After washing, the anthers were pos-fixed in osmium tetroxide $1 \%$ in phosphate buffer at room temperature for two hours, and in bloc contrasted with uranil acetate $2 \%$ for one hour. After dehydration in grades of ethanol, the material was embedded in low viscosity resin (Spurr 1969). The ultrathin sections were made with a diamond knife in an ultramicrotome Leica ULTRACUT-E. The sections were mounted in cooper slots with $1 \times 2 \mathrm{~mm}$ oval hole, coated with Formvar film and then contrasted with lead citrate (Venable \& Coggeshall 1965). The electron micrographs were taken in a Zeiss EM-10 transmission electron microscopy, under $60 \mathrm{kV}$.

\section{Results}

The floral and anther development, related to starch and protein contents, are resumed in figure 1. During the sporogenesis and gametogenesis there are two starch cycles, interrupted by one of protein. The first starch cycle comes from sporophytic origin and the second one, more intensive and longer, from gametophytic activity. Plastids containing starch grains are present in the androspore mother cells before the end of meiosis (figure 2) and they are regularly distributed in the cytoplasm. The plastids are shared after the simultaneous cytocinesis (figure 3 ). During the callose dissolution in the tetrads, the androspores contain small starch grains surrounding the nucleus (figure 4). In this early stage of development, a pectic primexine and a rudimental exine, constituted by a thin nexine and small bacules, envelop the haploid cell. In the next stage, the free androspores in the locular fluid show a increase of starch grain size, simultaneous with the emergence of PAS-positive onci, which have a lenticular shape (figure 5).

The androspore growth is accelerated by the coalescence and enlargement of the vacuoles. The spore wall shows a well-developed structure, with an intectate and clavate sexine and a thick nexine (figure 6). The cell content is polarized and the starch grains are absent. The nucleus has one or two nucleoli with some nucleolar vacuoles. In this stage, protein bodies are accumulated in the cytoplasmic vacuole and a thin layer of protein nature is located in the tonoplast periphery (figure 11).

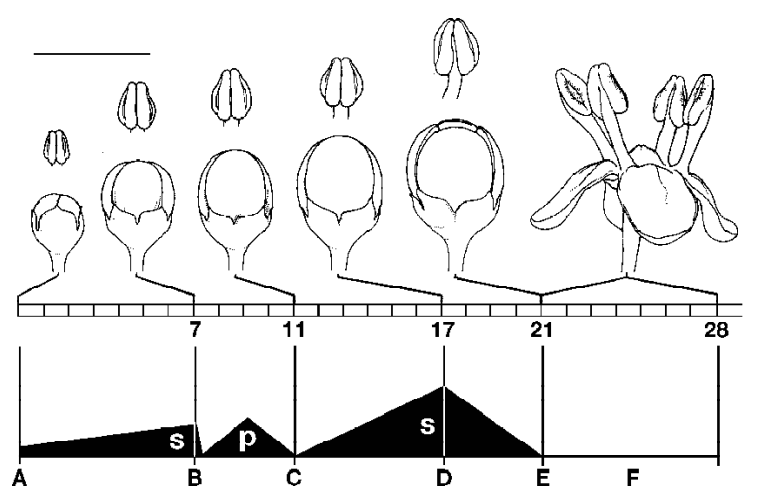

Figure 1. Anthers and staminate flowers development of Ilex paraguariensis and starch and protein dynamics. The numbers in the horizontal scale indicate days after the stage of androspore mother-cells and tetrads with calose (A), which contain small starch grains, in a floral bud with $1.4 \mathrm{~mm}$ of diameter. In the sequence, after seven days (B), dissolution of the callose and vacuolation of the androspores with increase in the starch grain size followed by abrupt consumption of starch, simultaneously with the accumulation of vacuolar proteins; 11 days (C), mitosis of the androspore and the beginning of the second cycle of starch sinthesis, after a degradation of protein bodies; 17 days (D), enclosed of the generative cell and maximum content of starch; 21 days (E), full consumption of starch and formation of the male germ unit; 21-28 days (F), dehiscent anthers with starchless pollen grains. s: starch cycle; p: protein cycle. Bar: $3 \mathrm{~mm}$. 

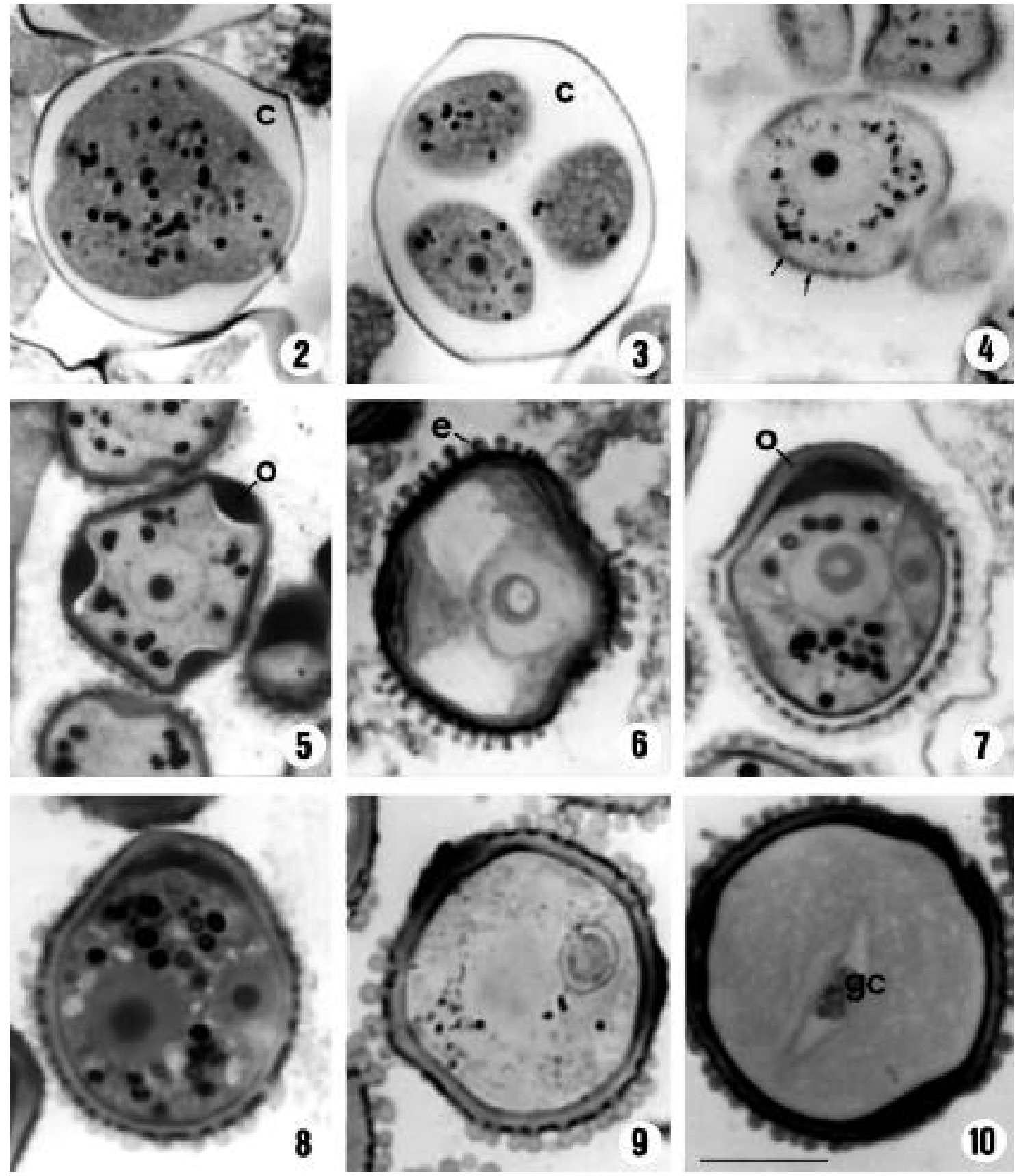

Figures 2-10. Semithin sections stained with PAS - toluidine blue, showing the starch grains during the sporogenesis and male gametogenesis in I. paraguariensis. All the figures are in the same scale. 2. Telophase in the androspore mother cell, enveloped by callose (c). 3. Tetrad with callose (c). 4. Androspore during the dissolution of callose. A thin primexine is visible (arrows). 5. Non-vacuolated androspore with a well-developed wall. In each aperture zone, a lens-shaped oncus (o) is conspicuous. 6. Vacuolated stage. The nucleus has a nucleolar vacuole and the cytoplasm is disproved of starch. The exine (e) shows typical clavae. 7. Bicellular stage with a generative cell in parietal position and a vegetative cell rich in starch. The oncus (o) is collapsed and a PAS-positive layer is present in the aperture. 8. Embracing the generative cell. The vegetative nucleus lost the vacuole. 9. Advanced stage with a fully enclosed generative cell. The starch grains are reduced in number and size. 10. Mature male gametophyte with a falciform generative cell (gc). Bar: $10 \mu \mathrm{m}$. 
After mitosis, with the formation of the vegetative and generative cells, a new accumulation of starch grains begins, limited to vegetative cytoplasm (figures 7 and 8). Their size is bigger than the starch of the first cycle. With the progressive collapse of the vacuole, the protein bodies are fragmented (figure 12) and disappear in the mature pollen grain. Similarly to the androspore, the vegetative nucleus has a conspicuous nucleolus with a nucleolar vacuole (figure 7). Now, a PAS-positive reaction occurs in a new pollen wall layer in the aperture zones, under

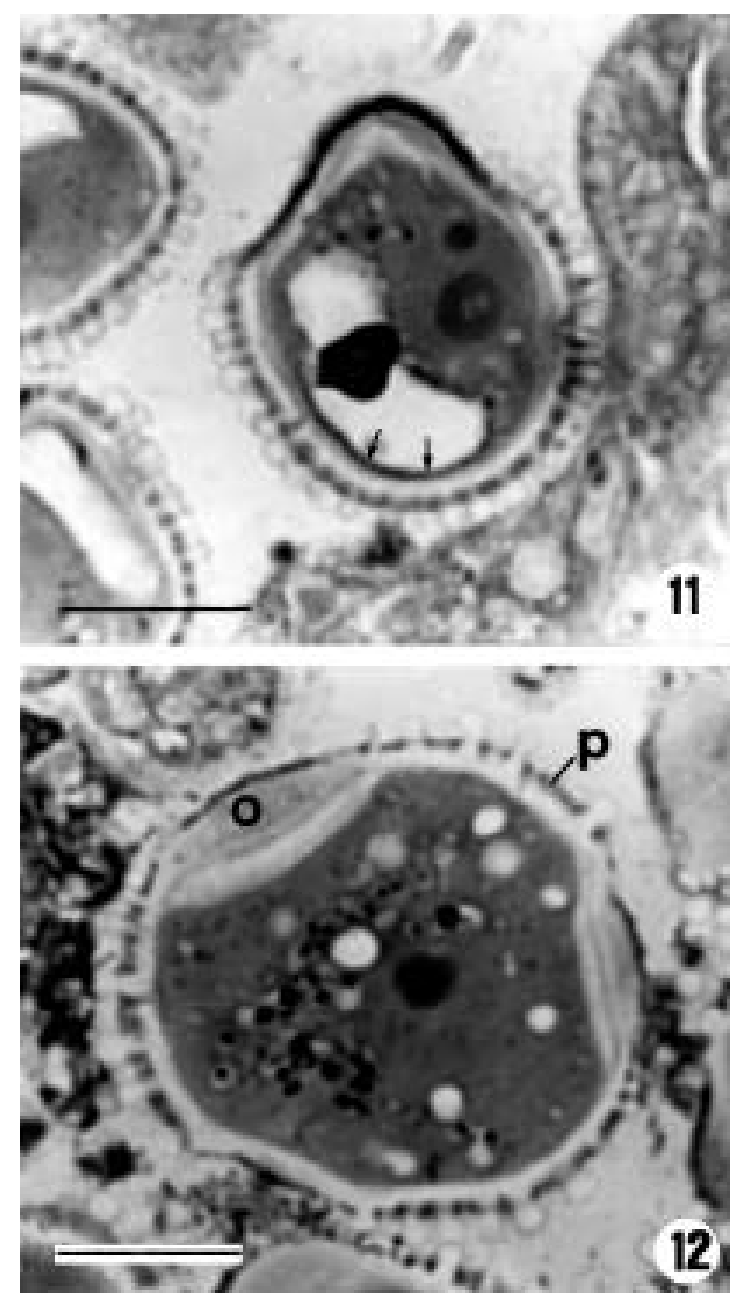

Figures 11-12. Semithin sections stained with Coomassie blue, showing the protein cycle during gametogenesis. 11. Protein bodies in the vacuole. A protein film (arrows) coats the periphery of the vacuole. Bar: $10 \mu \mathrm{m} .12$. After the mitosis. The collapsing vacuole, in the vegetative cytoplasm, has small protein particles. The persistent primexine $(\mathrm{p})$ has a protein constitution and the oncus (o) is not totally collapsed. Bar: $10 \mu \mathrm{m}$. the oncus completely or partially collapsed (figure 7 and 12), and in a thin wall that separates the generative and vegetative cells (figure 7).

The starch grains in the vegetative cell are progressively assimilated as the generative cell is enclosed and it begins to approach of the vegetative nucleus. Before elongation of the generative cell, spherical at this stage, starch can be found in the vegetative cytoplasm (figure 9).

In the mature pollen grain the generative cell is found in the central zone of the vegetative cell, which is PAS positive, and do not have starch as a reserve substance (figure 10).

Ultrastructurally the bicellular gametophyte contains lipid droplets surrounding the generative cell in a very closed contact, next to its thin and wavy cell wall (figure 13). The starch grains, in a assimilatory stage, occupy most of the plastid matrix. The pollen wall has an electron dense exine, externally covered with an amorphous primexine, between the clavae, except in the apertures. Besides the pectic composition, the primexine has also a protein component (figure 12). In the apertures, a polysaccharide Z-layer is biestratified and very thick but thin in the mesocolpi. The collapsed oncus is continuous with the lamellate nexine-2.

The mature pollen grain has many lipids droplets filling the vegetative cell (figures 14 and 15). The few plastids do not have starch and they present a very dense matrix. The vegetative nucleus embraces the generative cell, forming a male germ unit (figure 15). In the apertures, the Z-layer is covered by a thin layer of exine. A continuous intine with a regular thickness, although a little more thick under the aperture, is the last layer of the sporoderm. Pollenkitt covers the exine in some places (fig. 15).

\section{Discussion}

The accumulation of reserve substances is a characteristic of the pollen development and it appears to be the main function of the vegetative cell before the pollen germination (Knox 1984). The presence of these metabolites is diversified in the big variety of Angiosperms. Some species of Angiosperms do not have starch in the mature male gametophyte (Stanley \& Linskens 1974). However, "starchy" or "starchless" pollen can occur in a same anther (Franchi \& Pacini 1988). Baker \& Baker (1979) 
found 238 species with starchy pollen and 752 with starchless pollen of 990 species studied in 124 families of Angiosperms. The Aquifoliaceae family was classified in the category of starchless pollen. Our observations, in this paper, confirm this diagnostic.

In an ecological standpoint, the absence of starch is a feature of entomophilous species (Baker \& Baker 1979). The PAS-positive reaction of the vegetative cytoplasm, in mature pollen grains of Ilex paraguariensis, denotes a presence of soluble sugars. In combination with this aspect, the adhesive pollenkitt gluing the pollen grains and the highly ornamented structure of the pollen wall, are strong indicatives of entomophilous pollination (Knox 1984). The proteins found in the persistent primexine may increase the nutritive value of the pollen for the insects, mainly bees, which need a large supply of protein diet (Stanley \& Linskens 1974). However, its role in the stigma recognition and compatibility processes during the pollen-stigma interaction has not been rejected.

During the pollen development of Angiosperms, two or more waves of amylogenesis and amylolysis are common. In dicotyledons two waves occur, while in monocotyledons there are more than two (Pacini \& Franchi 1988). Differences between the diploid and haploid starch were described for Oenothera (Noher de Halac et al. 1992) showing two cycles of amylolyse/amylogenesis. Heslop-Harrison (1979) suggests a direct association between the P-particles and the degradation of starch grains. P-particles with their microfibrillar content appear to be the main precursors of the wall during the pollen tube growth, forming aggregates that fuses with the intine (HeslopHarrison 1987, Weber 1988). In addition, a P-particle origin was found from starch and lipid bodies in Lilium longiflorum (Miki-Hirosige \& Nakamura 1982). A reduction was observed in the amount of starch after the deposition of the oncus and before the mitosis, with the synthesis of the Z-layer, present in the aperture zones, also called medine (Saad 1963). Both layers have a polysaccharide composition in $I$. paraguariensis (Mariath et al. 1995). Like the first wave of starch, the second lysis is simultaneous with a new deposition of Z-layer and intine. After the formation of the vegetative and generative cells in the mature pollen grain, the polysaccharide layers of the pollen wall are enlarged, with two sub-layers in the Z-layer, and one layer in the intine (Santos 1995).
Like the intine, the nexine-2 has a polysaccharide composition mixed with sporopolenin (Walter \& Doyle 1975, Horner \& Pearson 1978, Santos 1995). In I. paraguariensis, the nexine- 2 has an enlargement of thickness until the vacuolated stage. This layer could also be a target of starch use during the first cycle too. Therefore, the starch degradation may be linked to pollen wall deposition (polysaccharide layers).

The androspore and vegetative nucleus show a great nucleolar activity, linked to the presence of nucleolar vacuoles (Risueño et al. 1988). This feature denotes a high ribosomal and transcriptional RNA synthesis and thus, a high proteinous synthesis. According to Mascarenhas (1975) the rRNA present in the ribosomes of mature pollen grains is mainly synthesized before mitosis and persist for a short period in the vegetative nucleus, according to the nuclear appearance in Ilex. The nuclear status in this stage could be associated with the capacity of producing starch-degrading enzymes. Analogous connection between nuclear appearance and starch degradation was found in the female gametophyte of Araucaria angustifolia (Rosado et al. 1994).

The ontogeny of the sperms in trinucleate pollen is another factor that promotes the use of metabolical stores. Trinucleate pollen grains are poor in reserve substances due to their consumption in the second mitotic division (Brewbaker 1957). Although binuclear in maturity (Santos 1995), the pollen grains of $I$. paraguariensis are starchless. There is a relationship between the vegetative nucleus and the generative cell in I. paraguariensis (R.P. dos Santos, unpublished data), configuring a male germ unit (Dumas et al. 1984). It was proved that the spatial union in the male germ unit requires energy during the movements of the vegetative nucleus and generative cell with ATPase activity (Pei-Hua 1988). The formation of male germ unit in $I$. paraguariensis uses up energy and it is probably that the starch serves as the main energetic source as well as the lipid bodies found in the vegetative cytoplasm. Lipids surrounding the generative cell are also typical in Paeonia (Sunderland \& Huang 1987). The physiological significance is still uncertain but possibly it has a role in the energy support while there is motility and the cell is changing the shape.

Plant proteins are synthesized in the endoplasmic reticulum, initially stored like small bodies on the tonoplast and later, in the vacuole (Raghavan 1986). 


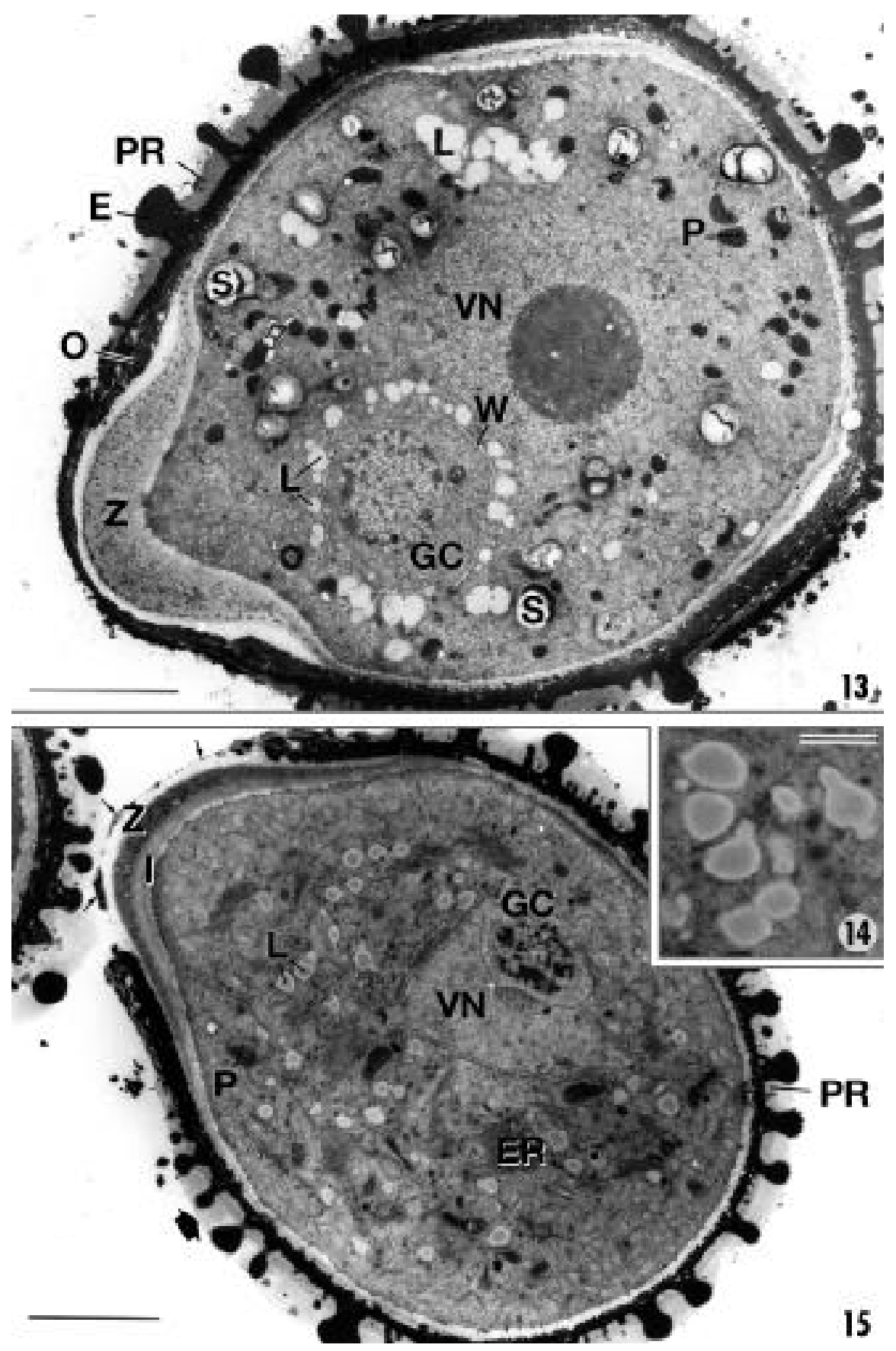

Figures 13-15. Electron micrography of the young male gametophyte (13) and of the mature male gametophyte of I. paraguariensis (14-15) in equatorial view. 13. The generative cell (GC) is surrounded by lipid droplets (L) next to a thin and wavy cell wall (W). Lipids are present in other zones of the vegetative cytoplasm. The plastids $(\mathrm{P})$ still contain starch grains ( $\mathrm{S}$ ). The pollen wall is constituted by the clavate exine (E), the pectic primexine (PR) and the biestratified Z-layer $(Z)$, thickened in the showing aperture. The oncus $(\mathrm{O})$ is collapsed. Bar: $4 \mu \mathrm{m}$. 14. Detail of the lipid droplets in the mature vegetative cell. Bar: $1 \mu \mathrm{m}$. 15. The vegetative cell is rich in lipid droplet $(\mathrm{L})$ mixed with endoplasmic reticulum $(\mathrm{RE})$ and some plastids $(\mathrm{P})$. The vegetative nucleus $(\mathrm{VN})$ envelops partially the generative cell (GC), in a cross section of the higher axis. The Z-layer is biestratified, recovered by exine traces (small arrows). The intine (I) is the last polysaccharide layer. Pollenkitt (big arrow) covers the exine and the primexine (PR) between the clavae. Bar: $4 \mu \mathrm{m}$. 
In I. paraguariensis, the spore cell stores vacuolar proteins after the starch grains of the first cycle have been consumed. Their presence may be associated with the first mitotic division, since the cell is deprived of another reserve and needs energy supply. Another aspect is the possible role of proteins in generating cellular polarity. The protein granules that disintegrate during the mitotic prophase may be responsible for the growth of the vacuoles, pressing the nucleus against the wall (Stanley \& Linskens 1974). This interesting possibility could explain the peripherical location of proteins inside the vacuole, which would be promoting their expansion. Nevertheless, this assumption can only be proved by means of ongoing ultrastructural experiments.

\section{References}

BAKER, H.G. \& BAKER, I. 1979. Starch in Angiosperms pollen grains and its evolutionary significance. Am. J. Bot. 66:591-600.

BREWBAKER, J.L. 1957. Pollen cytology and selfincompatibility systems in plants. J. Heredity 48:271-277.

DUMAS, C., KNOX, R.B., McCONCHIE, C.A. \& RUSSELL, S.D. 1984. Emerging physiological concepts in fertilization. What's New Plant Physiol 15:17-20

FRANCHI, G.G. \& PACINI, E. 1988. Pollen polysaccharide in some plants of economic interest. In Sexual reproduction in higher plants (M. Cresti, P. Gori \& E. Pacini, eds.). SpringerVerlag, Heidelberg, p. 473.

GABRIEL, B.L.1982. Biological electron microscopy. Van Nostrand Reinhold Company, New York.

HESLOP-HARRISON, J. 1979. Aspects of the structure, cytochemistry and germination of the pollen of rye (Secale cereale L.). Ann. Bot. 44 (supl.):1-47.

HESLOP-HARRISON, J. 1987. Pollen germination and pollentube growth. In Pollen: cytology and development. (G.G. Bourne, ed.). International review of cytology 107, Academic Press Inc., London. p.1-78.

HORNER, H.T. \& PEARSON, C.B. 1978. Pollen wall aperture development in Helianthus annus (Compositae:Heliantheae). Am.J.Bot. 65:293-309.

KNOX, R.B. 1984. The pollen grain. In Embryology of Angiosperms (B.M. Johri, ed.). Springer-Verlag, Heidelberg, p.197-271.

MARIATH, J.E.A., COELHO, G.C., SANTOS, R.P., HEUSER, E.D., AYUB, D.M. \& COCUCCI, A.E. 1995. Aspectos anatômicos e embriológicos em espécies do gênero Ilex. In Erva-Mate: Biologia e cultura no Cone Sul. (H.Winge, A.G.Ferreira, J.E.A.Mariath \& L.C. Tarasconi, eds.). Ed.Universidade/UFRGS, Porto Alegre, p.263-280.
MASCARENHAS, J.P. 1975. The biochemistry of Angiosperm pollen development. The Bot. Rev. 41:259-314.

MIKI-HIROSIGE, H. \& NAKAMURA, S. 1982. Process of metabolism during pollen tube wall formation. J. Electron Microsc. 31:51-62.

NOHER DE HALAC, I., FAMA, G. \& CISMONDI, I.A. 1992. Changes in lipids and polysaccharides during pollen ontogeny in Oenothera anthers. Sex Plant Reprod. 5:110-116.

O'BRIEN, T.P. \& MCCULLY, M.E. 1981. The study of plant structure principles and selected methods. Termarcarphi Pty Ltd, Melbourne.

PACINI, E. \& FRANCHI, G.G. 1988. Amylogenesis and amylolysis during pollen grain development. In Sexual reproduction in higher plants (M. Cresti, P. Gori \& E. Pacini, eds.). Springer-Verlag, Heidelberg, p.181-186.

PEI-HUA, T. 1988. Interaction of vegetative nucleus and generative cell (then sperms). In Sexual reproduction in higher plants (M. Cresti, P. Gori \& E. Pacini, eds.). Springer-Verlag, Heidelberg. p.227-232.

RAGHAVAN, V. 1986. Embryogenesis in Angiosperms. A developmental and experimental study. Cambridge University Press, London.

RISUEÑO, M.C., TESTILLANO, P.S. \& SÁNCHES-PINA, M.A 1988. Variations of nucleolar ultrastructure in relation to transcriptional activity during $\mathrm{G}_{1}, \mathrm{~S}$, and $\mathrm{G}_{2}$ periods of microspore interphase. In Sexual reproduction in higher plants (M. Cresti, P. Gori \& E. Pacini, eds.). Springer-Verlag, Heidelberg, p.9-14.

ROSADO, R.M., FERREIRA, A.G., MARIATH, J.E.A. \& COCUCCI, A.E. 1994. Amido no megagametófito de Araucaria angustifolia (Bert.) O. Ktze: degradação durante a germinação e desenvolvimento de esporófito. Acta Bot. Bras. 8:35-43.

SAAD, S.I. 1963. Sporoderm stratification: the "medine": a distinct third layer in the pollen wall. Pollen Spores 5:17-39.

SANTOS, R.P. 1995. O andrófito de Ilex paraguariensis St. Hil.: estrutura e citoquímica do tubo polínico e grão de pólen. Dissertação de mestrado, Universidade Federal do Rio Grande do Sul, RS.

SOUTHWORTH, D. 1973. Cytochemical reactivity of pollen walls. J. Histochem. Cytochem. 21:73-80.

SPURR, A.R. 1969. A low-viscosity epoxy resin embedding medium for electron microscopy. J. Ultrastruct. Res. 26:31-43.

STANLEY, R.G. \& LINSKENS, H.K. 1974. Pollen: biology, biochemistry, management. Springer-Verlag, New York.

SUNDERLAND, N. \& HUANG, B. 1987. Ultrastructural aspects of pollen dimorphism. In Pollen: cytology and development. (G.G. Bourne, ed.). International Review of Cytology 107, Academic Press Inc., London. p.175-220.

VENABLE, J.H \& COGGESHALL, R. 1965. A simplified lead citrate stain for use in electron microscopy. J. Cell Biol. 25:407.

WALTER, J.W. \& DOYLE, J.A. 1975. The bases of the Angiosperm Phylogeny: Palynology. Ann. Missouri Bot. Garden 62:664-723.

WEBER, M. 1988. Metabolism of P-particles (polysaccharide particle) in mature pollen grains of Eryngium campestre L. (Apiaceae). Protoplasma 146:65-71. 